\title{
Added Value of QuantiFERON TB-Gold in-Tube for Detecting Latent Tuberculosis Infection among Persons Living with HIV/AIDS
}

\author{
Josiane Maria Oliveira Souza, ${ }^{1,2}$ Maria do Socorro Nantua Evangelista, ${ }^{1,3}$ \\ and Anete Trajman ${ }^{4,5}$ \\ ${ }^{1}$ University of Brasilia (UnB), Campus Universitário Darcy Ribeiro, 70910-900 Brasília, DF, Brazil \\ ${ }^{2}$ SHA, Conjunto 5 chácara 47, Quadra D, Arniqueiras, 71995-297 Taguatinga, DF, Brazil \\ ${ }^{3}$ Catholic University of Brasilia (UCB), Campus I, QS 07 Lote 01 EPCT, Águas Claras, 71966-700 Taguatinga, DF, Brazil \\ ${ }^{4}$ Federal University of Rio de Janeiro (UFRJ), Avenida Brigadeiro Trompowsky $s / n^{\circ}$, Ilha do Fundão Prédio do Hospital Universitário \\ Clementino Fraga Filho, $11^{\circ}$ andar Bloco F, Sala 4, 21941-590 Rio de Janeiro, RJ, Brazil \\ ${ }^{5}$ Montreal Chest Institute, McGill University, 3650 St. Urbain Street, Montreal, QC, Canada H2X 2P4
}

Correspondence should be addressed to Josiane Maria Oliveira Souza; josianemaria@unb.br

Received 30 January 2014; Accepted 13 May 2014; Published 29 May 2014

Academic Editor: Christen Rune Stensvold

Copyright (C) 2014 Josiane Maria Oliveira Souza et al. This is an open access article distributed under the Creative Commons Attribution License, which permits unrestricted use, distribution, and reproduction in any medium, provided the original work is properly cited.

\begin{abstract}
Objective. To evaluate the added value of QuantiFERON TB-Gold in-Tube (QTF-GIT) over the tuberculin skin testing (TST) for detecting latent tuberculosis (TB) infection (LTBI) among patients with AIDS in a city with a low TB incidence rate (11.1/100,000 inhabitants) and universal BCG coverage. Methods. Three hundred consecutive patients with AIDS in eight outpatient sexually transmitted disease public clinics in Brasilia were submitted to QFT-IT and TST between May 2011 and March 2013. A positive result of either test was considered to be LTBI. Results. Median CD4-cell count was $477.5 \mathrm{cell} / \mathrm{s} / \mathrm{mm}^{3} ; 295(98.3 \%)$ were using antiretroviral therapy. Eighteen patients (6\%, 95\% CI: 3.6\%-9.3\%) had LTBI, of whom 4 (1.3\%, 95\% CI: $0.04 \%-2.63 \%)$ had only a positive TST, $8(2.7 \%, 95 \%$ CI: $0.8 \%-4.5 \%)$ had only a QFT-GIT positive test, and $6(2 \%, 95 \%$ CI: $0.4 \%-3.6 \%)$ had positive results for both tests. This represents an $81.8 \%$ relative increase in LTBI detection when QFT-GIT is added to TST. The concordance between both tests was $96 \%(k=0.48)$. Conclusions. The QFT-GIT alone was more effective to detect LTBI than TST alone and had an $81 \%$ added value as an add-on sequential test in this population with mild immunosuppression. The cost-effectiveness of these strategies remains to be evaluated.
\end{abstract}

\section{Introduction}

Persons living with HIV/AIDS (PLWHA) have a 20- to 37fold increased risk for developing active tuberculosis (TB) [1], which is a leading cause of death among them [2, 3]. Treatment of latent tuberculosis infection (LTBI) can significantly reduce the risk of progression for active TB and of death among PLWHA $[1,3-5]$. Thus, detection and treatment of latent TB infection (LTBI) is a priority in this population, and periodic testing is recommended in many guidelines [6-9].

Tuberculin skin testing (TST) has been used to detect LTBI for over a century. However, there are many limitations to its programmatic, public health use: reduced sensitivity in PLWHA, reduced specificity in BCG vaccinated populations (in particular when repeated tests are needed), need for two visits for tuberculin injection and induration reading, and need for adequate training of healthcare workers (HCW) $[10,11]$. Interferon-gamma release assays (IGRAs) have the advantage of one unique visit and are less operator-dependent [11].

All tests for LTBI detection have lower sensitivity in PLWHA [11, 12]. Although it is controversial, in most studies comparing IGRAs in PLWHA, the T-SPOT.TB (Oxford Immunotec, Abingdon, UK), an Elispot technique-based 
TABLE 1: Characteristics of 300 participants with AIDS according to the presence of LTBI detected by TST or QFT-GIT in Brasilia, Federal District, Brazil.

\begin{tabular}{|c|c|c|}
\hline Characteristics & $\begin{array}{c}\text { With LTBI } \\
(n=18) \\
n(\%)\end{array}$ & $\begin{array}{l}\text { Without LTBI } \\
\begin{array}{c}(n=282) \\
n(\%)\end{array}\end{array}$ \\
\hline \multicolumn{3}{|l|}{ Sex } \\
\hline Male & $15(7.0)$ & $200(93.0)$ \\
\hline Female & $3(3.5)$ & $82(96.5)$ \\
\hline \multicolumn{3}{|l|}{ Schooling (years) } \\
\hline$<9$ years & $18(18.4)$ & $80(81.6)$ \\
\hline $9-12$ years & - & $105(100)$ \\
\hline$>12$ years & - & $97(100)$ \\
\hline \multicolumn{3}{|l|}{ Marital status } \\
\hline Single & $12(7.2)$ & $154(92.8)$ \\
\hline Married & $2(3.8)$ & $51(96.2)$ \\
\hline Divorced & $2(8.3)$ & $22(91.7)$ \\
\hline Widower & - & $11(100)$ \\
\hline Living together & $2(4.3)$ & $44(95.7)$ \\
\hline \multicolumn{3}{|l|}{ Monthly income* } \\
\hline None & $2(8.7)$ & $21(91.3)$ \\
\hline$<1$ minimum wage & $5(10.0)$ & $45(90.0)$ \\
\hline 1-5 minimum wages & $7(4.4)$ & $152(95.6)$ \\
\hline$>5$ minimum wage & $4(5.9)$ & $64(94.1)$ \\
\hline \multicolumn{3}{|l|}{ Alcohol intake } \\
\hline Yes & $11(6.9)$ & $148(93.1)$ \\
\hline No & $7(5.0)$ & $134(95.0)$ \\
\hline \multicolumn{3}{|l|}{ Smoking habit } \\
\hline Yes (ever) & $1(3.8)$ & $25(96.2)$ \\
\hline No & $17(6.2)$ & $257(93.8)$ \\
\hline \multicolumn{3}{|l|}{ BCG vaccination } \\
\hline Yes & $15(6.6)$ & $213(93.4)$ \\
\hline No & $3(4.2)$ & $69(95.8)$ \\
\hline \multicolumn{3}{|l|}{ Doses of $\mathrm{BCG}^{\dagger}$} \\
\hline One & $14(6.7)$ & $196(93.3)$ \\
\hline Two & $1(5.6)$ & $17(94.4)$ \\
\hline \multicolumn{3}{|c|}{$\begin{array}{l}\text { History of contact with index } \\
\text { case }\end{array}$} \\
\hline No & $16(6.2)$ & $243(93.8)$ \\
\hline Yes & $1(2.9)$ & 34 (97.1) \\
\hline No information & $1(16.7)$ & $5(83.3)$ \\
\hline \multicolumn{3}{|l|}{$\mathrm{CD} 4$ count } \\
\hline$\geq 200$ cells $/ \mathrm{mm}^{3}$ & $17(6.3)$ & $253(93.7)$ \\
\hline$<200$ cells $/ \mathrm{mm}^{3}$ & $1(3.3)$ & $29(96.7)$ \\
\hline
\end{tabular}

Legend: LTBI: latent tuberculosis infection; BCG: Bacillus Calmette-Guérin. ${ }^{*}$ Minimum wage $=615.00$ Brazilian reais, equivalent to 349.40 American dollars at the time of data collection.

${ }^{\dagger}$ Percentage calculated over those vaccinated with BCG.

IGRA, had a slightly better accuracy $[11,13]$ than QuantiFERON TB-Gold in-Tube (QFT-GIT, Cellestis, Carnegie, Australia), an ELISA-based IGRA which has been adopted
TABLE 2: Agreement between TST and QFT test results in 300 patients with AIDS in Brasilia, Federal District, Brazil.

\begin{tabular}{lcccc}
\hline & & \multicolumn{3}{c}{ TST } \\
& & $\geq 5 \mathrm{~mm}$ & $<5 \mathrm{~mm}$ & Total \\
\hline \multirow{3}{*}{ QFT-GIT } & Positive & 6 & 8 & 14 \\
& Negative & 4 & 281 & 285 \\
Total & Indeterminate & 0 & 1 & 1 \\
& & $\mathbf{1 0}$ & $\mathbf{2 9 0}$ & $\mathbf{3 0 0}$ \\
\hline
\end{tabular}

NOTE: Kappa $=0.48 ; P$-value $<0.001$.

Legend: TST: tuberculin skin testing; QTF-GIT: QuantiFERON TB-Gold inTube.

by many developed countries for LTBI detection $[6,14-$ 17] in this population. Nevertheless, IGRAs have not been considered cost-effective in immunocompetent adults from the National Public Health System in Brazil (SUS) [18].

The objective of the present study was to evaluate the added value of QFT-GIT over the TST for detecting LTBI among PLWHA in Brasilia, the capital of Brazil, a city with a low TB incidence rate (11.1/100.000 inhabitants) and universal coverage by BCG. We also explored the factors associated with a positive QFT-GIT and with discordant QFT-GIT/TST results.

\section{Methods}

A cross-sectional study was conducted in eight outpatient sexually transmitted disease public clinics between May 2011 and March 2013. Patients diagnosed with AIDS according to Rio de Janeiro/Caracas or adapted CDC criteria [19] living in Brasilia, Federal District, were eligible. Those over 17 years who were not submitted to TST in the previous five weeks were consecutively invited to participate and included if they signed an informed consent. Patients with history of other immunosuppression conditions were excluded: severe AIDSrelated opportunistic infections, acute viral infections, those submitted to any vaccination in the previous two months, and those using immunosuppressive drugs. Patients with present or past active $\mathrm{TB}$ and those with a history of a previous positive TST were also excluded. The sample size was calculated to be 300 to have an $80 \%$ power, considering a $5 \%$ type I error to detect an association of a positive test with six variables (patients' characteristics).

After signing the informed consent, participants answered a questionnaire about sociodemographic, clinical, and epidemiological information. CD4-cell count and antiretroviral therapy data (ART) were extracted from medical records. Participants were then submitted to TST using $0.1 \mathrm{~mL}$ of PPD-RT 23 (corresponding to 2 units of tuberculin). Injection and reading of induration 72 to 96 hours after injection were performed by a trained HCW. QFT-GIT was performed according to the manufacturer's instruction [20].

Patients were considered to have LTBI if TST induration was $\geq 5 \mathrm{~mm}$ or if the difference between interferon response to $\mathrm{TB}$ antigens and negative control was $\geq 0.35 \mathrm{UI} / \mathrm{mL}$ and interferon response to $\mathrm{TB}$ antigens was $\geq 25 \%$ compared 
TABLE 3: TST results according to characteristics of 300 patients with AIDS in Brasilia, Federal District, Brazil.

\begin{tabular}{|c|c|c|c|c|}
\hline Characteristics & $\begin{array}{c}\text { TST positive } \\
n(\%)\end{array}$ & $\begin{array}{c}\text { TST negative } \\
n(\%)\end{array}$ & $\begin{array}{l}\text { Nonadjusted } \\
\text { OR }(95 \% \text { CI })\end{array}$ & $\begin{array}{c}\text { Adjusted } \\
\text { OR }(95 \% \text { CI })\end{array}$ \\
\hline \multicolumn{5}{|l|}{ Sex } \\
\hline Male & $9(4.2)$ & $206(95.8)$ & $3.67(0.46-29.42)$ & $4.27(0.40-45.58)$ \\
\hline Female & $1(1.2)$ & $84(98.8)$ & 1.0 (reference) & 1.0 (reference) \\
\hline \multicolumn{5}{|l|}{ Schooling (years) } \\
\hline$<9$ years & $2(3.4)$ & $56(96.6)$ & $1.04(0.22-5.05)$ & $1.26(0.20-7.95)$ \\
\hline$\geq 9$ years & $8(3.3)$ & $234(96.7)$ & 1.0 (reference) & 1.0 (reference) \\
\hline \multicolumn{5}{|l|}{ Single } \\
\hline Yes & $7(4.2)$ & $159(95.8)$ & $1.92(0.49-7.58)$ & $1.37(0.30-6.33)$ \\
\hline No & $3(2.2)$ & $131(97.8)$ & 1.0 (reference) & 1.0 (reference) \\
\hline \multicolumn{5}{|l|}{ Monthly income* } \\
\hline None & $2(8.7)$ & $21(91.3)$ & $2.06(0.32-13.20)$ & $2.37(0.28-20.02)$ \\
\hline$<1$ minimum wage & $2(4.0)$ & $48(96.0)$ & $0.90(0.14-5.61)$ & $1.88(0.21-16.83)$ \\
\hline 1-5 minimum wages & $3(1.9)$ & $156(98.1)$ & $0.42(0.08-2.12)$ & $0.59(0.11-3.29)$ \\
\hline$>5$ minimum wages & $3(4.4)$ & $65(95.6)$ & 1.0 (reference) & 1.0 (reference) \\
\hline \multicolumn{5}{|l|}{ Alcohol intake } \\
\hline Yes & $8(5.0)$ & $151(95.0)$ & $3.68(0.77-17.64)$ & $2.52(0.49-12.82)$ \\
\hline No & $2(1.4)$ & $139(98.6)$ & 1.0 (reference) & 1.0 (reference) \\
\hline \multicolumn{5}{|l|}{ Smoking habit } \\
\hline Yes (ever) & $1(2.9)$ & $34(97.1)$ & $0.84(0.10-6.67)$ & $0.72(0.08-6.25)$ \\
\hline No & $9(3.4)$ & $256(96.6)$ & 1.0 (reference) & 1.0 (reference) \\
\hline \multicolumn{5}{|l|}{ BCG vaccination } \\
\hline Yes & $8(3.5)$ & $220(96.5)$ & $1.27(0.26-6.13)$ & $1.13(0.20-6.35)$ \\
\hline No & $2(2.8)$ & $70(97.2)$ & 1.0 (reference) & 1.0 (reference) \\
\hline \multicolumn{5}{|c|}{$\begin{array}{l}\text { History of contact with index } \\
\text { case }\end{array}$} \\
\hline Yes & $1(2.9)$ & 34 (97.1) & $0.92(0.11-7.61)$ & $1.21(0.13-11.16)$ \\
\hline No & $8(3.1)$ & $251(96.9)$ & 1.0 (reference) & 1.0 (reference) \\
\hline No information & $1(16.7)$ & $5(83.3)$ & - & - \\
\hline \multicolumn{5}{|l|}{ CD4 count, ${ }^{\S}$} \\
\hline$<200$ cells $/ \mathrm{mm}^{3}$ & - & $30(100)$ & $0.76(0.10-6.25)$ & - \\
\hline$\geq 200$ cells $/ \mathrm{mm}^{3}$ & $10(3.7)$ & $260(96.3)$ & 1.0 (reference) & - \\
\hline \multicolumn{5}{|l|}{ Doses of BCG, ${ }^{\dagger, \S}$} \\
\hline One & $8(3.8)$ & $202(96.2)$ & 0.00 & - \\
\hline Two & - & $18(100)$ & 1.0 (reference) & - \\
\hline
\end{tabular}

Legend: LTBI: latent tuberculosis infection; BCG: Bacillus Calmette-Guérin; TST: tuberculin skin testing.

${ }^{*}$ Minimum wage $=615.00$ Brazilian reais, equivalent to 349.40 American dollars at the time of data collection.

${ }^{\dagger}$ Percentage calculated over those vaccinated with BCG.

${ }^{\S}$ One unit added to all cells to allow OR calculation.

to the negative control response. QFT-GIT was considered to be indeterminate if the interferon response to the negative control was $\geq 8 \mathrm{UI} / \mathrm{mL}$ or $<0.5 \mathrm{UI} / \mathrm{mL}$ compared to the positive control. Although the Brazilian guidelines [21] recommend treating only those with a positive TST, all participants considered to have LTBI, regardless of the test, were forwarded to preventive isoniazid therapy $[11,16]$.

The number of detected LTBI cases by any test and the number of additional LTBI cases detected by a positive QFT-GIT test as an add-on test as well as the number necessary to test (NTT) and their exact 95\% confidence intervals (CI) were calculated. Concordance of test results was compared using kappa statistics. The association of independent variables and a positive result was estimated by the adjusted odds ratio (OR) in a multivariate model using logistic regression using the SPSS package, version 20 (Chicago, IL).

The study was approved by the Institutional Review Board of the Federal District Health Secretariat (Document 0019/2011). 
TABLE 4: QFT-GIT results according to characteristics of 300 patients with AIDS in Brasilia, Federal District, Brazil.

\begin{tabular}{|c|c|c|c|c|}
\hline Characteristics & $\begin{array}{c}\text { QTF-GIT positive } \\
n(\%) \\
\end{array}$ & $\begin{array}{c}\text { QTF-GIT negative } \\
n(\%)\end{array}$ & $\begin{array}{l}\text { Nonadjusted } \\
\text { OR }(95 \% \mathrm{CI}) \\
\end{array}$ & $\begin{array}{c}\text { Adjusted } \\
\text { OR }(95 \% \mathrm{CI}) \\
\end{array}$ \\
\hline \multicolumn{5}{|l|}{ Sex } \\
\hline Male & $12(5.6)$ & $202(94.4)$ & $2.46(0.54-11.26)$ & $4.70(0.86-25.59)$ \\
\hline Female & $2(2.4)$ & $83(97.6)$ & 1.0 (reference) & 1.0 (reference) \\
\hline \multicolumn{5}{|l|}{ Schooling (years) } \\
\hline$<9$ years & $5(8.6)$ & $53(91.4)$ & $2.43(0.78-7.55)$ & $2.41(0.65-8.87)$ \\
\hline$\geq 9$ years & $9(3.7)$ & $232(96.3)$ & 1.0 (reference) & 1.0 (reference) \\
\hline \multicolumn{5}{|l|}{ Single } \\
\hline Yes & $9(5.5)$ & $156(94.5)$ & $1.49(0.49-4.55)$ & $1.19(0.35-4.03)$ \\
\hline No & $5(3.7)$ & $129(96.3)$ & 1.0 (reference) & 1.0 (reference) \\
\hline \multicolumn{5}{|l|}{ Monthly income* } \\
\hline None & $2(8.7)$ & $21(91.3)$ & $6.38(0.55-73.94)$ & $6.55(0.50-86.21)$ \\
\hline$<1$ minimum wage & $4(8.0)$ & $46(92.0)$ & $5.83(0.63-53.81)$ & $7.40(0.66-82.21)$ \\
\hline $1-5$ minimum wages & $7(4.4)$ & $151(95.6)$ & $3.11(0.37-25.75)$ & $3.09(0.35-26.91)$ \\
\hline$>5$ minimum wages & $1(1.5)$ & $67(98.5)$ & 1.0 (reference) & 1.0 (reference) \\
\hline \multicolumn{5}{|l|}{ Alcohol intake } \\
\hline Yes & $8(5.1)$ & $150(94.9)$ & $1.20(0.41-3.55)$ & $1.09(0.34-3.49)$ \\
\hline No & $6(4.3)$ & $135(95.7)$ & 1.0 (reference) & 1.0 (reference) \\
\hline \multicolumn{5}{|l|}{ Smoking habit } \\
\hline Yes (ever) & $1(2.9)$ & $34(97.1)$ & $0.57(0.07-4.54)$ & $0.44(0.05-3.70)$ \\
\hline No & $13(4.9)$ & $251(95.1)$ & 1.0 (reference) & 1.0 (reference) \\
\hline \multicolumn{5}{|l|}{ BCG vaccination } \\
\hline Yes & $12(5.3)$ & $215(94.7)$ & $1.95(0.43-8.94)$ & $2.09(0.16-28.05)$ \\
\hline No & $2(2.8)$ & $70(97.2)$ & 1.0 (reference) & 1.0 (reference) \\
\hline \multicolumn{5}{|l|}{ Doses of $\mathrm{BCG}^{\dagger}$} \\
\hline Two & $1(5.6)$ & $17(94.4)$ & $0.94(0.11-7.76)$ & $0.81(0.09-7.47)$ \\
\hline One & $11(5.3)$ & $198(94.7)$ & 1.0 (reference) & 1.0 (reference) \\
\hline \multicolumn{5}{|l|}{ CD4 count } \\
\hline$<200$ cells $/ \mathrm{mm}^{3}$ & $1(3.3)$ & $29(96.7)$ & $0.68(0.08-5.26)$ & $0.58(0.07-5.00)$ \\
\hline$\geq 200$ cells $/ \mathrm{mm}^{3}$ & $13(4.8)$ & $256(95.2)$ & 1.0 (reference) & 1.0 (reference) \\
\hline \multicolumn{5}{|c|}{$\begin{array}{l}\text { History of contact with index } \\
\text { case }^{\S}\end{array}$} \\
\hline Yes & - & $35(100)$ & $0.49(0.06-3.82)$ & - \\
\hline No & $13(5.0)$ & $245(95.0)$ & 1.0 (reference) & - \\
\hline No information & $1(16.7)$ & $5(83.3)$ & - & - \\
\hline
\end{tabular}

Legend: LTBI: latent tuberculosis infection; BCG: Bacillus Calmette-Guérin; QTF-GIT: QuantiFERON TB-Gold in-Tube.

${ }^{*}$ Minimum wage $=615.00$ Brazilian reais, equivalent to 349.40 American dollars at the time of data collection.

${ }^{\dagger}$ Percentage calculated over those vaccinated with BCG.

${ }^{\S}$ One unit added to all cells to allow OR calculation.

\section{Results}

The characteristics of the 300 participants according to their LTBI status are displayed in Table 1 . Their median age was 40 (interquartile range: $\mathrm{IQR}=32-46$ ) years; median $\mathrm{CD} 4$ cell count was 477.5 (95\% CI: $450.5-504.5)$ cells $/ \mathrm{mm}^{3} ; 295$ (98.3\%) were using ART. Eighteen (6.0\%, 95\% CI: 3.6\%9.3\%) had LTBI, of whom 10 (55.6\%, 95\% CI: $30.8 \%-78.5 \%)$ were detected with TST. Out of those, $6(60 \%, 95 \%$ CI: $26.2 \%-87.8 \%)$ and an additional 8 had a positive QFT-GIT.
In other words, $3.3 \%$ (95\% CI: $1.3 \%-5.7 \%)$ had a positive TST, out of whom $1.3 \%$ could only be detected by a positive TST, while $2.7 \%$, nearly half of those with LTBI, could only be detected with the QFT-GIT test, representing an $81.8 \%$ relative increase in LTBI detection when added to TST. One QFT-GIT had an indeterminate result. Although income was not significantly associated with LTBI (using a cut-off of 1 minimum wage, $\mathrm{OR}=2.1 ; 95 \% \mathrm{CI}$ : $0.8-5.9 ; P=0.16$ ), lower schooling was as follows: all patients with LTBI had under 9 years of schooling (OR $=47.6$; 95\% CI: 6.3-361.6; $\left.P<10^{-8}\right)$. 
TABLE 5: Discordant and concordant results of QTF-GIT and TST according to characteristics of 300 patients with AIDS in Brasilia, Federal District, Brazil.

\begin{tabular}{|c|c|c|c|c|}
\hline Characteristics & $\begin{array}{c}\text { Discordant result } \\
n(\%)\end{array}$ & $\begin{array}{c}\text { Concordant result } \\
n(\%) \\
\end{array}$ & $\begin{array}{l}\text { Nonadjusted } \\
\text { OR }(95 \% \text { CI })\end{array}$ & $\begin{array}{c}\text { Adjusted } \\
\text { OR }(95 \% \text { CI }) \\
\end{array}$ \\
\hline \multicolumn{5}{|l|}{ Sex } \\
\hline Male & $9(4.2)$ & $206(95.8)$ & $0.83(0.22-3.16)$ & $0.59(0.12-2.86)$ \\
\hline Female & $3(3.5)$ & $82(96.5)$ & 1.0 (reference) & 1.0 (reference) \\
\hline \multicolumn{5}{|l|}{ Schooling (years) } \\
\hline$<9$ years & $5(8.6)$ & $53(91.4)$ & 1.0 (reference) & 1.0 (reference) \\
\hline$\geq 9$ years & $7(2.9)$ & $234(97.1)$ & $3.15(0.96-10.32)$ & $6.31(1.28-31.22)$ \\
\hline \multicolumn{5}{|l|}{ Single } \\
\hline Yes & $8(4.8)$ & $157(95.2)$ & 1.0 (reference) & 1.0 (reference) \\
\hline No & $4(3.0)$ & $130(97.0)$ & $1.66(0.49-5.62)$ & $1.57(0.41-5.98)$ \\
\hline \multicolumn{5}{|l|}{ Monthly income*§ } \\
\hline None & - & $23(100)$ & - & - \\
\hline$<1$ minimum wage & $4(8.0)$ & $46(92.0)$ & $0.72(0.17-3.02)$ & $1.73(0.25-12.22)$ \\
\hline 1-5 minimum wages & $4(2.5)$ & $155(97.5)$ & $2.41(0.58-9.92)$ & $3.85(0.78-18.96)$ \\
\hline$>5$ minimum wages & $4(5.9)$ & $64(94.1)$ & 1.0 (reference) & 1.0 (reference) \\
\hline \multicolumn{5}{|l|}{ Alcohol intake } \\
\hline Yes & $6(3.8)$ & $152(96.2)$ & $1.13(0.35-3.57)$ & $1.15(0.34-3.92)$ \\
\hline No & $6(4.3)$ & $135(95.7)$ & 1.0 (reference) & 1.0 (reference) \\
\hline \multicolumn{5}{|l|}{ BCG vaccination } \\
\hline Yes & $10(4.4)$ & $218(95.6)$ & 1.0 (reference) & 1.0 (reference) \\
\hline No & $2(2.8)$ & 70 (97.2) & $1.61(0.34-7.54)$ & $5.47(0.35-84.32)$ \\
\hline \multicolumn{5}{|l|}{ Doses of $\mathrm{BCG}^{\dagger}$} \\
\hline Two & $1(5.6)$ & $17(94.4)$ & $1.31(0.16-10.94)$ & $2.48(0.24-25.64)$ \\
\hline One & $9(4.3)$ & $201(95.7)$ & 1.0 (reference) & 1.0 (reference) \\
\hline \multicolumn{5}{|l|}{ CD4 count } \\
\hline$<200$ cells $/ \mathrm{mm}^{3}$ & $1(3.3)$ & $29(96.7)$ & $1.24(0.15-9.92)$ & $1.27(0.13-12.22)$ \\
\hline$\geq 200$ cells $/ \mathrm{mm}^{3}$ & $11(4.1)$ & $258(95.9)$ & 1.0 (reference) & 1.0 (reference) \\
\hline \multicolumn{5}{|l|}{ Smoking habit ${ }^{\S}$} \\
\hline Yes (ever) & - & $35(100)$ & $1.85(0.23-14.57)$ & - \\
\hline No & $12(4.5)$ & $253(95.5)$ & 1.0 (reference) & - \\
\hline \multicolumn{5}{|c|}{$\begin{array}{l}\text { History of contact with index } \\
\text { case }^{\S}\end{array}$} \\
\hline Yes & $1(2.9)$ & $34(97.1)$ & 0.00 & - \\
\hline No & $11(4.3)$ & $248(95.7)$ & 1.0 (reference) & - \\
\hline No information & - & $6(100)$ & - & - \\
\hline
\end{tabular}

Legend: LTBI: latent tuberculosis infection; BCG: Bacillus Calmette-Guérin; TST: tuberculin skin testing; QTF-GIT: QuantiFERON TB-Gold in-Tube.

${ }^{*}$ Minimum wage $=615.00$ Brazilian reais, equivalent to 349.40 American dollars at the time of data collection.

${ }^{\dagger}$ Percentage calculated over those vaccinated with BCG.

${ }^{\S}$ One unit added to all cells to allow OR calculation.

The NNT to detect one LTBI case was 30 using TST as a single test and 21.4 using QFT-GIT as a single test; the NNT with QFT as an add-on test to detect one additional case was 36.2. The concordance between both tests was $96 \%(k=0.48)$, mainly due to agreement on negative cases (Table 2). There was no significant association of the independent variables with a positive test result (Tables 3 and 4 ) or with discordant results (Table 5).

\section{Discussion}

In the present study, the prevalence of LTBI in PLWHA was low (6\%) [22-25] considering the population age. Although these data are consistent with other tuberculin surveys in Brazil $[26,27]$ and other countries $[22,23,28]$, this can be an underestimate, since sensitivity of both TST and QFT-GIT is suboptimal in PLWHA $[11,12]$. However, among those with lower educational background, prevalence was much higher 
(22.5\%), which confirms previous findings that TB infection is associated with socioeconomic class [29].

More importantly, QFT-GIT alone was more effective to detect LTBI than TST, assuming that any test is a marker of LTBI. This is important because despite absence of substantial evidence of the benefit of isoniazid preventive therapy in QFT-GIT positive patients, recent studies have shown a high risk of active TB in these patients $[2,7,29-31]$ and thus treatment of PLWHA with discordant tests has been recommended $[15,16]$ considering the high efficacy of isoniazid preventive therapy $[3,5,32]$ to prevent disease and death among these patients.

The added value of QFT-GIT in PLWHA has been explored in other countries with low burden and incidence rate of TB (Spain and USA), with variable findings. More modest effects of QFT in the absolute (less than 1.4\%) and relative (less than 20\%) increase in LTBI detection have been reported $[22,24,28]$. On the other hand, another study in Spain showed a similar result to ours: an absolute increase in $2.9 \%$ and relative increase in $47.8 \%$ (from $6.7 \%$ to $9.6 \%$ ) [23]. Another research carried out in Germany showed a higher increase in the QTF-GIT outcomes when compared to the TST, this time of $7.2 \%$ [25].

The best approach for LTBI screening in PLWHA remains to be defined and will likely be variable in different scenarios and populations, depending on TB incidence rates and stage of the disease. In our study, QFT-GIT as an add-on sequential test to TST doubled the detection of LTBI. However, due to the large difference in costs of both tests $[11,33]$, a costeffectiveness analysis considering both strategies is necessary. A cost-effectiveness study of QFT-GIT as an add-on test to confirm LTBI in Brazil has shown that this strategy was dominated (less effective and more costly). However, in this analysis, the base cases were immunocompetent individuals [18]. Moreover, no analysis was done to evaluate the added value for detecting more cases, since isoniazid preventive therapy is indicated in the country only for TST positive patients at present [21]. WHO does not recommend the use of IGRA as a replacement test for TST for PLWHA in poor low- and medium-income countries [33]. In case the Brazilian National TB Program considers following the CDC recommendations [8], cost-effectiveness analyses considering PLWHA and the added value of QFT-GIT to detect new LTBI cases will be necessary.

The study has a few limitations. TST is a readerdependent technique, which always raises concerns about its accuracy. However, all HCW in the present study were previously trained for injection of tuberculin and reading of induration. The low prevalence of positive results has limited the capacity to evaluate risk factors associated to positive results and to discordance associated factors. The transversal study design also hindered prospectively evaluating the TB incidence. These possible limitations are outweighed by its strengths: being a pragmatic study with routine data collection in the public health sector and responsible for assistance of over $1.5 \%$ of the Brazilian population with AIDS [34]. Although we should not generalize the present results to other populations, we believe that the present findings show a definite value of QFT-GIT in PLWHA in a medium-income country in a low TB prevalence scenario.

\section{Conclusions}

The QFT-GIT alone was more sensitive to detecting LTBI than TST and doubled the detection of LTBI when used as an add-on sequential test in this population with mild immunosuppression, in a region with low incidence rates of TB and universal coverage by BCG. However, due to the large difference in costs of both tests, a cost-effectiveness analysis considering both strategies is necessary among PLWHA.

\section{Conflict of Interests}

The authors declare that there is no conflict of interests regarding the publication of this paper.

\section{Acknowledgment}

This research was supported by Fundação de Apoio à Pesquisa do Distrito Federal, FAPDF funded by SUS-PPSUS Grant no. 193.000.353/2010.

\section{References}

[1] World Health Organization, Guidelines for Intensified Tuberculosis Case-Finding and Isoniazid Preventive Therapy for People Living with HIV in Resource-Constrained Settings, World Health Organization, Geneva, Switzerland, 2011.

[2] World Health Organization, Global Tuberculosis Report 2013, World Health Organization, Geneva, Switzerland, 2013.

[3] K. L. Dierberg and R. E. Chaisson, "Human immunodeficiency virus-associated tuberculosis. Update on prevention and treatment," Clinics in Chest Medicine, vol. 34, no. 2, pp. 217-228, 2013.

[4] T. Samandari, T. B. Agizew, S. Nyirenda et al., "6-month versus 36-month isoniazid preventive treatment for tuberculosis in adults with HIV infection in Botswana: a randomised, doubleblind, placebo-controlled trial," The Lancet, vol. 377, no. 9777, pp. 1588-1598, 2011.

[5] S. D. Lawn, R. Wood, K. M. de Cock, K. Kranzer, J. J. Lewis, and G. J. Churchyard, "Antiretrovirals and isoniazid preventive therapy in the prevention of HIV-associated tuberculosis in settings with limited health-care resources," The Lancet Infectious Diseases, vol. 10, no. 7, pp. 489-498, 2010.

[6] National Institute for Health and Clinical Excellence, Tuberculosis: Clinical Diagnosis and Management of Tuberculosis, and Measures for Its Prevention and Control, National Institute for Health and Clinical Excellence, London, UK, 2011.

[7] World Health Organization, WHO Policy on Collaborative TB/HIV Activities: Guidelines for National Programmes and Other Stakeholder, World Health Organization, Geneva, Switzerland, 2012.

[8] J. E. Kaplan, C. Benson, K. H. Holmes, J. T. Brooks, A. Pau, and H. Masur, "Guidelines for prevention and treatment of opportunistic infections in HIV-infected adults and adolescents: recommendations from $\mathrm{CDC}$, the national institutes of health, and the HIV medicine association of the infectious diseases society of America," Morbidity and Mortality Weekly Report: Recommendations and Reports, vol. 58, no. 4, pp. 1-207, 2009. 
[9] Ministério da Saúde (Brasil), Secretaria de Vigilância em Saúde, Departamento de DST, Aids e Hepatites Virais, Protocolo Clínico e Diretrizes Terapêuticas para Adultos vivendo com HIV/Aids: versão preliminar, Ministério da Saúde, Brasília, Brazil, 2013.

[10] D. Menzies, "Interpretation of repeated tuberculin tests: boosting, conversion, and reversion," The American Journal of Respiratory and Critical Care Medicine, vol. 159, no. 1, pp. 15-21, 1999.

[11] A. Trajman, R. E. Steffen, and D. Menzies, "Interferon-gamma release assays versus tuberculin skin testing for the diagnosis of latent tuberculosis infection: an overview of the evidence," Pulmonary Medicine, vol. 2013, Article ID 601737, 11 pages, 2013.

[12] M. Santin, L. Muñoz, and D. Rigau, "Interferon- $\gamma$ release assays for the diagnosis of tuberculosis and tuberculosis infection in HIV-infected adults: a systematic review and meta-analysis," PLoS ONE, vol. 7, no. 3, Article ID e32482, 2012.

[13] A. Cattamanchi, R. Smith, K. R. Steingart et al., "Interferongamma release assays for the diagnosis of latent tuberculosis infection in HIV-infected individuals: a systematic review and meta-analysis," Journal of Acquired Immune Deficiency Syndromes, vol. 56, no. 3, pp. 230-238, 2011.

[14] C. M. Denkinger, K. Dheda, and M. Pai, "Guidelines on interferon- $\gamma$ release assays for tuberculosis infection: concordance, discordance or confusion?" Clinical Microbiology and Infection, vol. 17, no. 6, pp. 806-814, 2011.

[15] Canada Communicable Disease Report, "Recommendations on interferon gamma release assays for the diagnosis of latent tuberculosis infection-2010 update," Canada Communicable Disease, An Advisory Committee Statement (ACS) and Canadian Tuberculosis Committee (CTC), vol. 36, no. 5, 2010.

[16] Centers for Disease Control and Prevention, "Updated guidelines for using interferon gamma release assays to detect Mycobacterium tuberculosis infection-United States, 2010," Morbidity and Mortality Weekly Report: Recommendations and Reports, vol. 59, no. 5, pp. 1-25, 2010.

[17] C. G. M. Erkens, M. Kamphorst, I. Abubakar et al., “Tuberculosis contact investigation in low prevalence countries: a European consensus," European Respiratory Journal, vol. 36, no. 4, pp. 925-949, 2010.

[18] R. E. Steffen, R. Caetano, M. Pinto et al., "Cost-effectiveness of quantiferon-TB gold-in-tube versus tuberculin skin testing for contact screening and treatment of latent tuberculosis infection in Brazil," PLoS ONE, vol. 8, no. 4, Article ID e59546, 2013.

[19] Ministério da Saúde (Brasil), Secretaria de Vigilância em Saúde, Programa Nacional de DST e Aids, Critérios de definição de casos de aids em adultos e crianças, Ministério da Saúde, Brasília, Brazil, 2003.

[20] Cellestis, QuantiFERON-TB Gold: Método in tubo, Teste de interferon-gama para sangue total, para medição de respostas aos péptidos antigénicos ESAT-6, CFP-10 \& TB7. 7, Folleto informativo para diagnóstico in vitro, Cellestis Limited, Australia e Cellestis GmbH, Hannover, Germany, 2009.

[21] Ministério da Saúde (Brasil), Secretaria de Vigilância em Saúde, Programa Nacional de Controle da Tuberculose, Manual de Recomendações para o Controle da Tuberculose no Brasil, Ministério da Saúde, Brasília, Brazil, 2011.

[22] A. F. Luetkemeyer, E. D. Charlebois, L. L. Flores et al., "Comparison of an interferon- $\gamma$ release assay with tuberculin skin testing in HIV-infected individuals," The American Journal of Respiratory and Critical Care Medicine, vol. 175, no. 7, pp. 737742, 2007.

[23] M. Santin, S. Casas, M. Saumoy et al., "Detection of latent tuberculosis by the tuberculin skin test and a whole-blood interferon- $\gamma$ release assay, and the development of active tuberculosis in HIV-seropositive persons," Diagnostic Microbiology and Infectious Disease, vol. 69, no. 1, pp. 59-65, 2011.

[24] N. J. Talati, U. Seybold, B. Humphrey et al., "Poor concordance between interferon- $\gamma$ release assays and tuberculin skin tests in diagnosis of latent tuberculosis infection among HIV-infected individuals," BMC Infectious Diseases, vol. 9, article 15, 2009.

[25] C. Stephan, T. Wolf, U. Goetsch et al., "Comparing QuantiFERON-tuberculosis gold, T-SPOT tuberculosis and tuberculin skin test in HIV-infected individuals from a low prevalence tuberculosis country," AIDS, vol. 22, no. 18, pp. 2471-2479, 2008.

[26] E. G. Teixeira, D. Menzies, G. W. Comstock et al., "Latent tuberculosis infection among undergraduate medical students in Rio de Janeiro State, Brazil," International Journal of Tuberculosis and Lung Disease, vol. 9, no. 8, pp. 841-847, 2005.

[27] K. Z. Siqueira and S. A. Mendonça, "Indicação da prova tuberculínica e infecção latente da tuberculose em HIV-positivos, Município de Blumenau, Estado de Santa Catarina, Brasil, 2004-2009," Epidemiologia e Serviços de Saúde, vol. 21, no. 4, pp. 635-644, 2012.

[28] J. M. Ramos, C. Robledano, M. Masiá et al., "Contribution of Interferon gamma release assays testing to the diagnosis of latent tuberculosis infection in HIV-infected patients: a comparison of QuantiFERON-TB gold in tube, T-SPOT.TB and tuberculin skin test," BMC Infectious Diseases, vol. 12, article 169, 2012.

[29] P. Narasimhan, J. Wood, C. R. MacIntyre, and D. Mathai, "Risk factors for tuberculosis," Pulmonary Medicine, vol. 2013, Article ID 828939, 11 pages, 2013.

[30] S. A. Clark, S. L. Martin, A. Pozniak et al., "Tuberculosis antigen-specific immune responses can be detected using enzyme-linked immunospot technology in human immunodeficiency virus (HIV)-1 patients with advanced disease," Clinical and Experimental Immunology, vol. 150, no. 2, pp. 238-244, 2007.

[31] M. C. Aichelburg, A. Rieger, F. Breitenecker et al., "Detection and prediction of active tuberculosis disease by a wholeblood interferon- $\gamma$ release assay in HIV-l-infected individuals," Clinical Infectious Diseases, vol. 48, no. 7, pp. 954-962, 2009.

[32] C. Akolo, I. Adetifa, S. Shepperd, and J. Volmink, "Treatment of latent tuberculosis infection in HIV infected persons," Cochrane Database of Systematic Reviews, no. 1, Article ID CD000171, 2010.

[33] World Health Organization, Use of Tuberculosis InterferonGamma Release Assays (IGRAs) in Low- and Middle-Income Countries: Policy Statement, World Health Organization, Geneva, Switzerland, 2011.

[34] Ministério da Saúde (Brasil), Secretaria de Vigilância em Saúde, Departamento de DST, Aids e Hepatites Virais, Boletim Epidemiológico-Aids e DST, Ano II-no. 1, até semana epidemiológica 26a, Ministério da Saúde, 2013. 


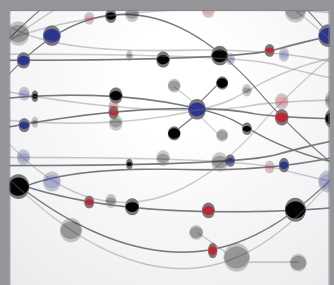

The Scientific World Journal
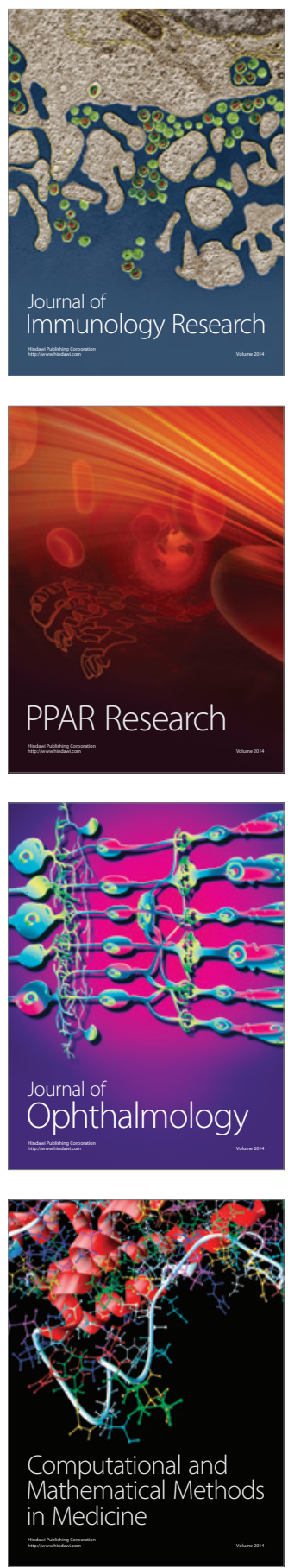

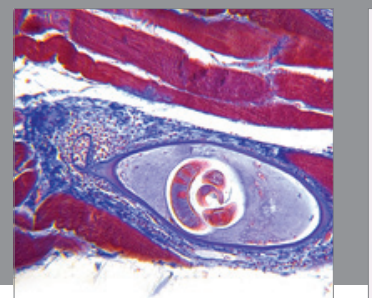

Gastroenterology

Research and Practice
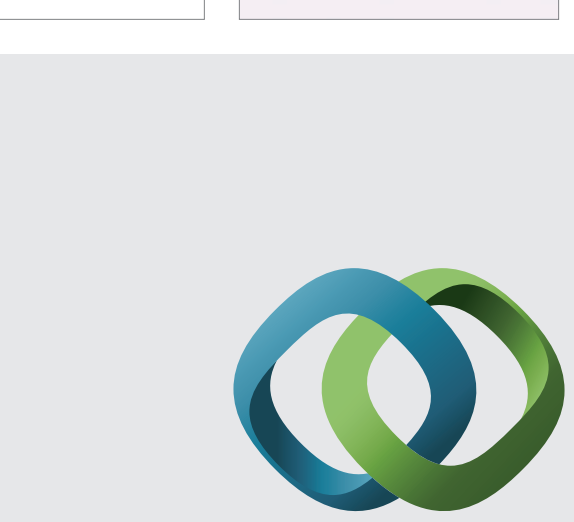

\section{Hindawi}

Submit your manuscripts at

http://www.hindawi.com
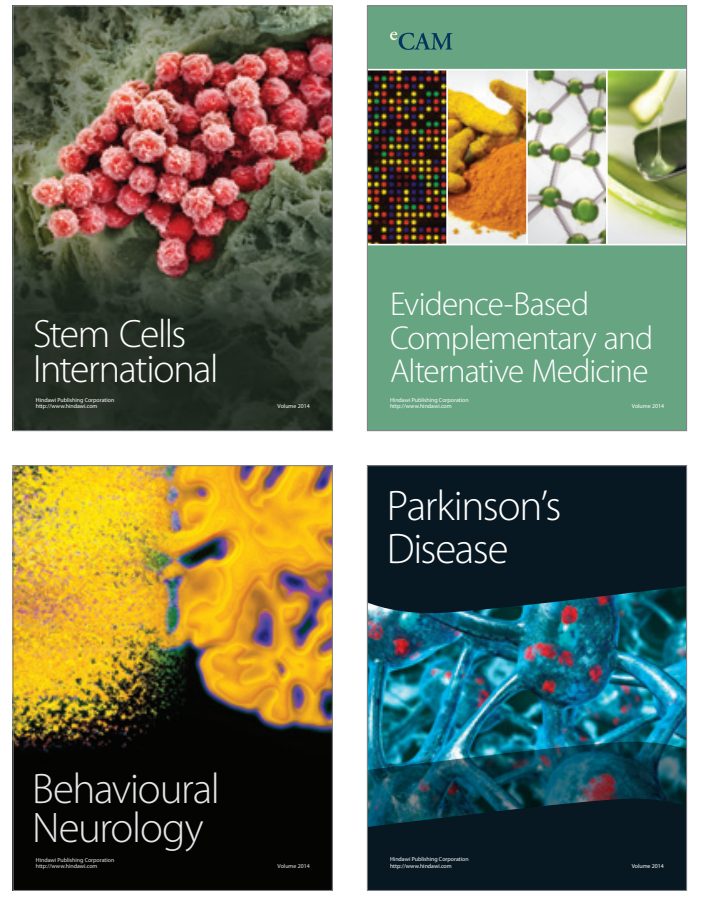
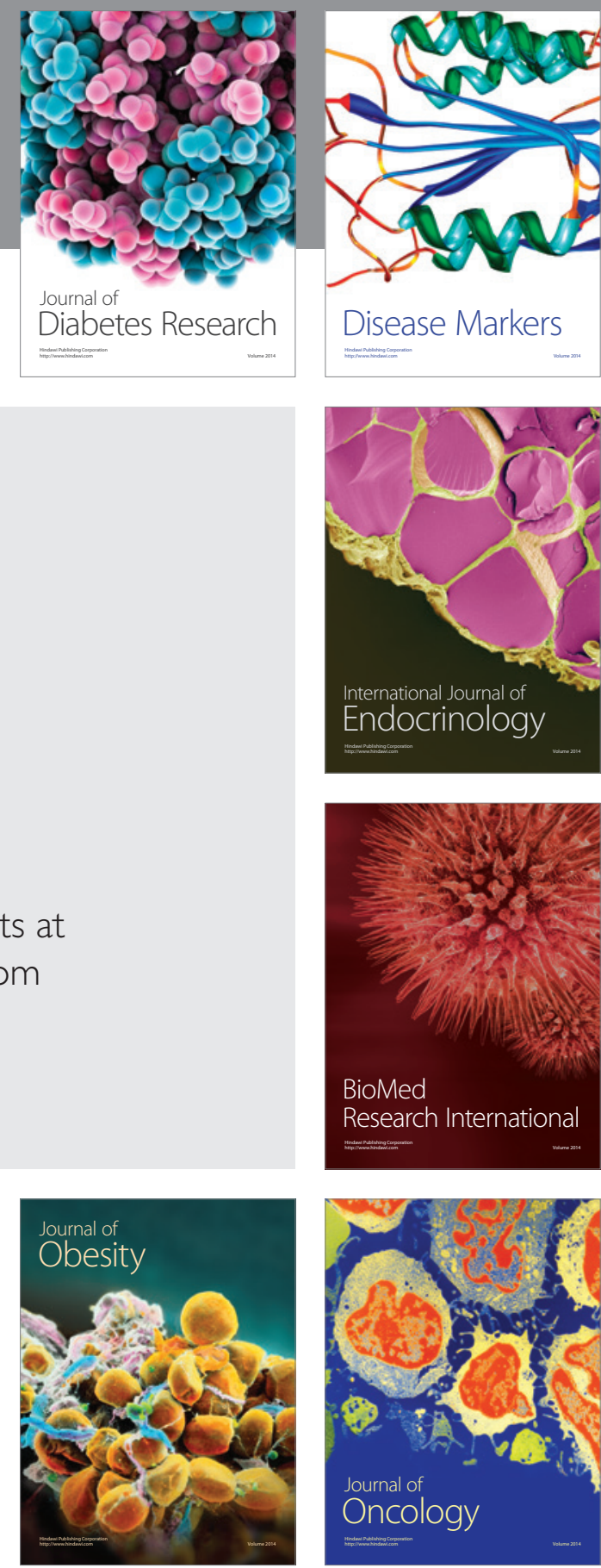

Disease Markers
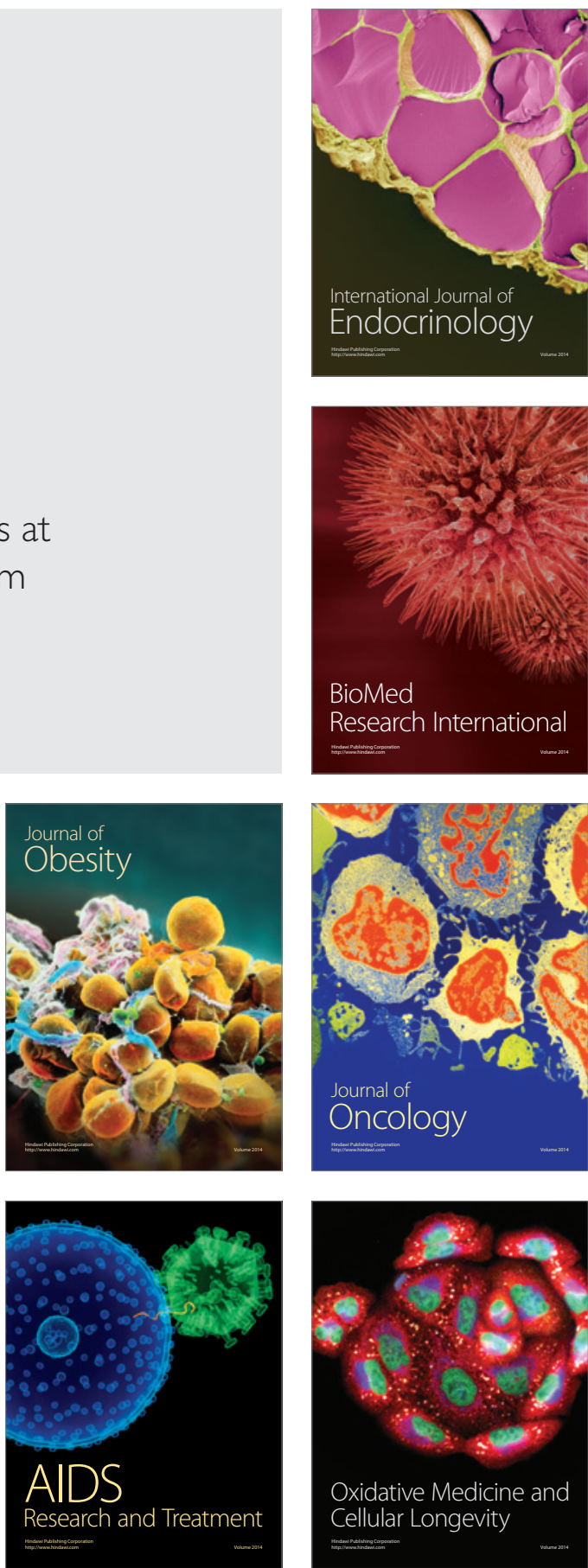